\title{
Issue of wayfinding concept in museum interiors
}

\author{
T. Sarihati, R. Firmansyah, S. Salayanti \& N. Hasanah A. Rosyad \\ Telkom University, Bandung, Indonesia
}

\begin{abstract}
The main purpose of museum management is to build knowledge and recreational facilities. Wayfinding has an important role in ensuring museum visitors get the most out of the purpose of visiting the museum. The presence of well-designed wayfinding encourages exploration, facilitates accessibility, and increases visitor interest in museums. This paper discusses to which extent interior wayfinding in museums is applied. The research derived from literature reviews in the form of books and journals, taken from academic research in the similar field related to the role and type of wayfinding in museums. The results achieved from this study were that museums have specific types of road search that are tailored to the information to be conveyed. The existence of wayfinding also provides another option for finding various ways.
\end{abstract}

Keywords: museum interior, wayfinding, flexibility, literature reviews

\section{INTRODUCTION}

Wayfinding is a means to provide information related to directions, special signs for certain locations. It is also an important factor to influence the people ability to find a way. Through experience with space, people acquire and encode environmental cues as spatial knowledge in cognitive maps that can be taken to improve road search performance (Lin et al. 2019). Road finding as a design problem outlines the logic of the design approach and illustrates that wayfinding design is fundamentally congruent with universal design (Romedi 1996). These design features include spatial planning, architectural features related to circulation, and graphic display including audible and touch (Romedi 1996).

The application of wayfinding in public spaces has been done, but only as information without a conceptual basis. Graphic marking or information systems are often presented to show space or direction and are generally in the form of written signs. The museum as a facility for obtaining information through collectibles or other objects should apply the concept of a good and clear interior wayfinding to facilitate visitors in exploring exhibitions displayed, achieving access to exit the museum, or reaching other areas easily and efficiently.

This research tried to find out the provisions about wayfinding in the museum and what the museum requires for its environmental development. It collected information about the museum, wayfinding in the museum, and how wayfinding influences the flexibility in public space especially museums.

The definition of a museum has evolved, in line with the development of society. Exhibition organizers and designers began to formulate how visitors to the exhibition could become the main characters in their experiences and see it from their perspective (Erlhoff \& Marshall 2007). Understanding a successful museum in the 21 st century is supporting visitors to their interests, needs, learning methods to participate in educating the public, socializing, and public meetings. Museums are no longer just institutions that preserve heritage (Crimm et al. 2009).

A museum is a place that stores history. Museum understanding of history is divided into four concepts of thinking: the concept of chronological thinking, periodization, diachronic, and synchronous. The concept of chronological thinking is the appreciation of visitors in the museum 
that consists of contemplation, understanding, discovery, and interaction. Visitors are invited to be more active and can be directly involved in an exhibition. One of the concepts put forward by Simon (2010) is participatory museums, a two-way interpersonal communication model that can be achieved through educational programs, participatory, living interpretations, and interactive exhibitions through various media such as audiovisual, touch screen, and multimedia.

Wayfinding is a system that provides predictable locations by various types of information and hierarchical instructions that enhance understanding and navigation in an environment. Multistory rooms that are not connected are often faced with the complex problem of providing a readable, economical, and easy-to-treat sign at every possible decision point in the search for this road (Gibson 2009). The function of the wayfinding is to give instructions to visitors who find it difficult to interpret the floor plan, the solution is to install navigation (number, sign, code) near the exhibition or at points of interest (Roussou \& Katifori 2018).

In the thesis "Effects of Design Features on Visitors' Behavior in a Museum Setting", it was stated that museums can play more than protectors of collections and accumulators of educational material, but also as providers of entertainment experience services. To offer the best possible service, wise decisions need to be made by considering how the arts and their environment interact with customers through the big picture formed by signage, the range of art exhibited, the time of the exhibition, and the placement of objects in space (Chang 2008).

Next, is the question on how the museum's interior environment, the quality of interior circulation design, and visitor satisfaction are interrelated in the context of the interior environment and museum space design. Whether the quality of interior circulation design and interior space design are direct determinants of visitor satisfaction or is there another significant relationship between the interior environment and interior elements such as lighting design, furniture, and material arrangement (Elottol \& Bahauddin 2011).

\section{METHOD}

This study used qualitative research methods through systematic, careful data collection, using comparisons and critical thinking. This method collects, analyzes, and interprets shared data. In interpreting data, qualitative researchers theoretically create new concepts and interpretations. Qualitative research methods do not only use or test past theories but also builds new theories (Berg \& Lune 2011; Groat \& Wang 2013; Lune \& Berg 2016; Neuman \& Neuman 2006).

Literature reviews is a method of selecting documents available on topics that contain information, ideas, data, and evidence written from a particular perspective to meet certain objectives or express certain views about the nature of the topic and how the research will be investigated, and effective evaluation of documents related to the proposed research. The purpose of the literature review is to show the subject area and understand the problem; to justify research topics, designs, and methodologies (Hart 2018; Rowley \& Slack 2004).

The data used in this study were obtained from other research conducted by previous researchers, taken from books and primary or original scientific reports contained in articles (printed or nonprinted) regarding wayfinding and its placement in the interior, especially of a museum. Source selection was based on (1) provenance (evidence), the aspects of the author's credentials and evidence support, (2) objectivity, whether the perspective idea from the author has many uses or is it detrimental; (3) persuasiveness, whether the author is a person who can be trusted; and (4) value, whether the author's argument has contributed to other significant research.

One of the main sources was a journal written by Heru Budi (2018), titled "Wayfinding Sign in the Permanent Exhibition Room at the National Museum of Indonesia". It was chosen for several considerations: its relevance with this study and the journal's reputation for content validity. Other main sources used were journals and books from D. Gibson (2009) and Lin et al. (2019). The data was analyzed through annotated bibliography and then concluded. 


\section{RESULTS AND DISCUSSION}

\subsection{Types of wayfinding in museums}

Table 1. Types of wayfinding.

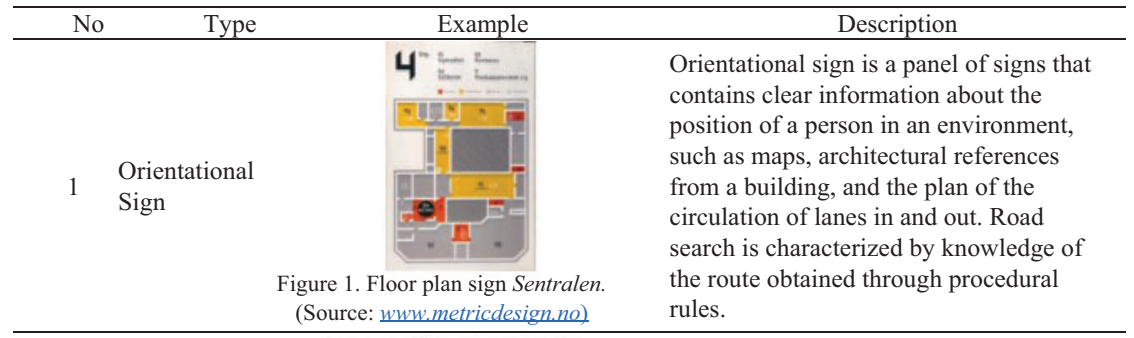

2 Information Sign

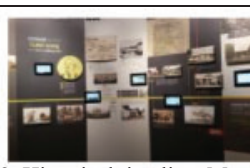

Figure 2. Historical timeline. Museum Gedung Sate, Bandung. (Source: https://museumgedungsate.org/galeri Museum)

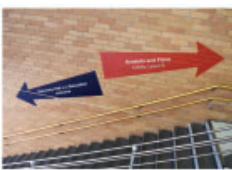

Figure 3. Floor direction. Science Museum of Minnesota. (Source: http://www.nicolesuek.com/museumsignage)

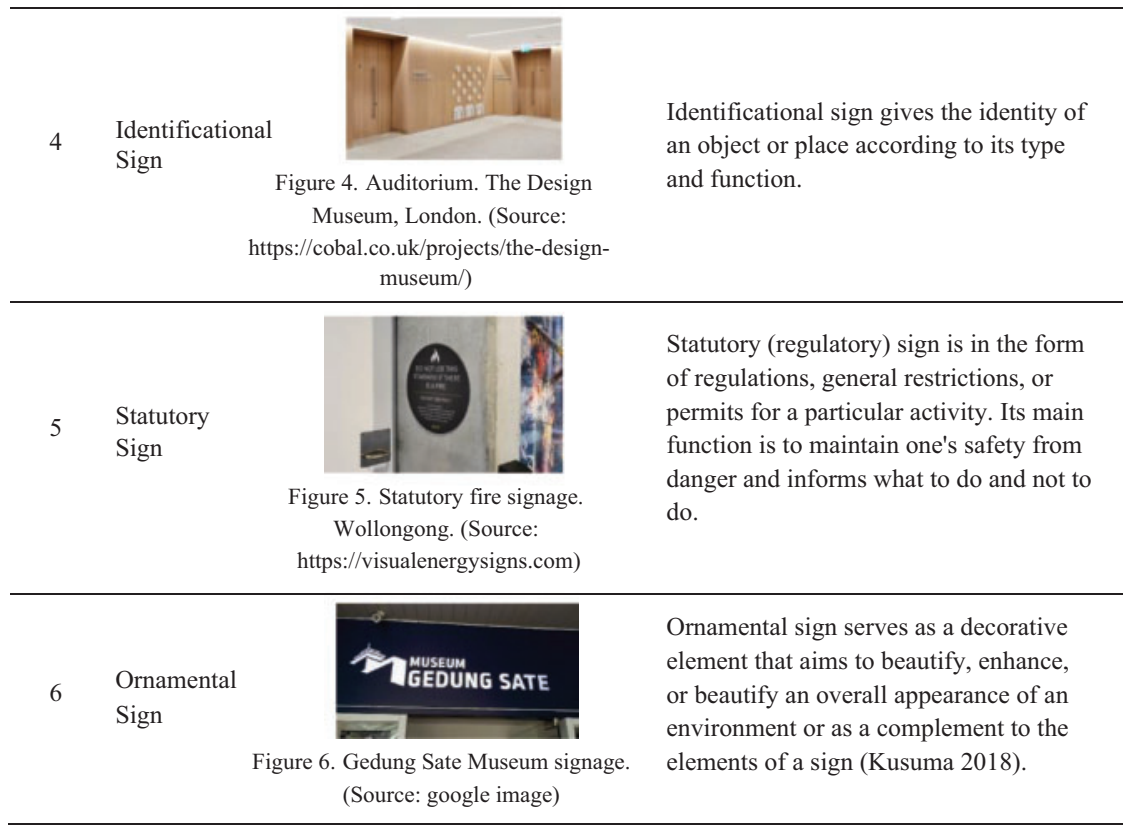

Informational sign refers to the specifics and details of information, with the sign form being adjusted to the information that is to be conveyed.

Directional sign shows the direction or location of the destination to be directed by visitors. This sign is an explicit navigation tool. It is expected to make visitors more efficient and comfortable in an environment. an object or place according to its type and function. of regulations, general restrictions, or permits for a particular activity. Its main function is to maintain one's safety from danger and informs what to do and not to

gure 5. Statutory fire signage Wollongong. (Source: (1) 


\subsection{Wayfinding function}

The function of wayfinding in buildings is to provide ease of circulation. The difficulty of finding a road is more difficult for people with physical impairments, particularly for people with sensory impairments. These difficulties can become architectural barriers that are psychological in terms of reducing accessibility as much as physical barriers (Romedi 1996). Wayfinding is associated with building security as a marker for emergency evacuation routes. Wayfinding design is intended to give users an easy understanding of space and time efficiency for museum staff so that the staff does not need to provide information to visitors.

Interior signage is displayed in color, size codes, and typographic style as information on objects and circulation. With many codes affecting interior signage, visual information content used on signage instead of words, must still be effective and easy to understand (Nabila \& Sarihati 2016).

There are many forms of information that can be used by designers to help build users understanding in navigating efficiently through the built space. Two types of information were assessed, the form of floor plans and signboards. They were found to interact in ways, sometimes, unexpected. The usefulness and types of signage varies greatly, although sometimes the difference is only a little in the complexity of a floor plan. Various aspects of wayfinding performances are affected differently depending on the combination of available architectural cues (O'Neill 1991).

The ease obtained in understanding space by wayfinding/signage includes aspects such as look and feel physically the use of signs in its colors or shapes, and the information to be conveyed. Wayfinding involves complex cognitive processes which include goal setting, perception, acquisition, judgment, and movement (Lin et al. 2019).

Wayfinding is an important factor to influence people's ability to find a way. The presence of signage in the form of a floor position in the room will make it easy for visitors to determine their location and provide clear instructions about circulation within. A person acquires and encodes environmental cues as spatial knowledge in cognitive maps that can be taken to improve the performance of ease of circulation and road search (Lin et al. 2019).

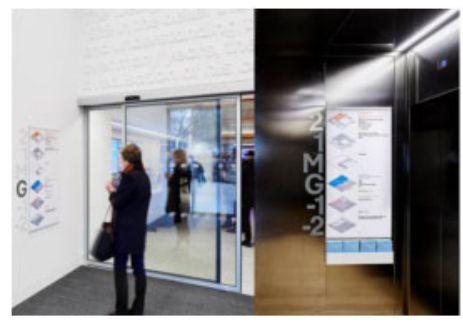

Figure 7. Floor position signage. The Design Museum, London. (Source: https://cobal.co.uk/projects/ the-design-museum/).

Wayfinding or topographic orientation is the ability to determine location, find a place in building facilities. The application of wayfinding can be in the form of very detailed details to form a pattern that can direct the flow of circulation of an environment (Kusuma 2018).

Built environment features are related to deliberate human circulation and their ability to mentally place themselves in an environment (Romedi 1996). These design features include spatial planning, architectural features related to circulation, and graphic display including audible support and touch (Romedi 1996).

In conditions of high density, wayfinding arrangements can help someone to find another way when there is a crowd on a route to be headed. The wayfinding also provides options for someone to look for other destinations that could be more interesting, to carry out a different direction search strategy, and choose different initial route options. As an anticipation, while we did not find the effect of density at the strategic or tactical level, participants in conditions of high density are more likely to move along environmental boundaries to avoid crowds ( $\mathrm{Li}$ et al. 2019). 


\section{CONCLUSION}

The concept of wayfinding in museums is based on its function as a means of education and recreation. Museums have a type of wayfinding that is more widely used, which is the informational sign. An informational sign consists of more to the specifics and details of information. The form of this sign is adjusted to the information to be conveyed.

The influence of wayfinding on the ease of upholding is to know one's position in a room and give clear instructions about circulation within. For example, it gives people another option to look for other goals that can be achieved when faced with the situation of a crowd. It becomes a special marker for some facilities that are specific to some extent such as destined to people with disabilities that affect the additional spatial planning.

\section{REFERENCES}

Berg, B.L. and Lune, H. 2011. Qualitative Methods for the Social Sciences.

Chang, T.-J. 2008. Effects of Design Features on Visitors' Behavior in a Museum Setting. The University of Kansas.

Crimm, W.L., Morris, M., and Wharton, C.L. 2009. Planning successful museum building projects. Rowman Altamira.

Elottol, R. and Bahauddin, A. 2011. The Relationship Between Interior Space Design and Visitors' Satisfaction: A Case Study of Malaysian Museums (Interior Circulation Scheme). International Journal of Organizational Innovation 3(4).

Erlhoff, M. and Marshall, T. 2007. Design dictionary: perspectives on design terminology. Walter de Gruyter.

Gibson, D. 2009. The wayfinding handbook: Information design for public places. Princeton Architectural Press.

Groat, L. N. and Wang, D. (eds). 2013. Architectural Research Methods 2nd Edition. New Jersey: John Wiley $\&$ Sons.

Hart, C. 2018. Doing a literature review: Releasing the research imagination. Sage.

Kusuma, H.B. 2018. Wayfinding Sign pada Ruang Pameran Tetap di Museum Nasional Indonesia - Jakarta. Mudra Jurnal Seni Budaya 33(2):242. doi: 10.31091/mudra.v33i2.331.

Li, H. et al. 2019. The Effect of Crowdedness on Human Wayfinding and Locomotion in a Multi-Level Virtual Shopping Mall. Journal of Environmental Psychology 65. doi: 10.1016/j.jenvp.2019.101320.

Lin, J., Cao, L., and Li, N. 2019. Assessing the Influence of Repeated Exposures and Mental Stress on Human Wayfinding Performance in Indoor Environments Using Virtual Reality Technology. Advanced Engineering Informatics 39:53-61. Elsevier. doi: 10.1016/j.aei.2018.11.007.

Nabila, S. and Sarihati, T. 2016. Peran Elemen Interior Sebagai Wayfinding Sirkulasi di Showroom Galeri Selasar Sunaryo Bandung. 3(3):1138-1149.

Neuman, W.L. and Neuman, L.W. 2006. Workbook for Neumann Social Research Methods: Qualitative and Quantitative Approaches. Allyn \& Bacon.

O'Neill, M.J. 1991. Effects of Signage and Floor Plan Configuration on Wayfinding Accuracy. Environment and Behavior 23(5):553-574. Thousand Oaks, CA: Sage Publications.

Romedi, P. 1996. Wayfinding Design: Logic, Application and Some Thoughts on Universality. Design Studies 17(3):319-331.

Roussou, M. and Katifori, A. 2018. Flow, Staging, Wayfinding, Personalization: Evaluating User Experience with Mobile Museum Narratives. Multimodal Technologies and Interaction 2(2):32. Multidisciplinary Digital Publishing Institute,

Rowley, J. and Slack, F. 2004. Conducting a Literature Review. Management Research News. Emerald Group Publishing Limited.

Wulandari, A. A. A. 2014. Dasar-Dasar Perencanaan Interior Musem. Humaniora, 5(1):246. 